\title{
WATER QUALITY INDEX FOR WATER SAMPLES OF RAJGHAT RESERVOIR IN SAGAR CITY, M.P., INDIA
}

\author{
Hemant Pathak ${ }^{1}$ \\ ${ }^{1}$ Department of Chemistry, Indira Gandhi Govt. Engineering College, Sagar, MP, India, E- \\ mail: hemantp1981@yahoo.co.in
}

Keywords: physico-chemical parameters, Water quality index, Regression analysis, seasons.

\begin{abstract}
The present work is aimed at assessing the water quality index (WQI) for the Rajghat reservoir water on Bewas River life line of Sagar city. This has been determined by collecting water samples from selected 5 locations covered entire reservoir, and subjecting the samples to a most important physico-chemical analysis. 14 parameters have been considered: DO, water temperature, Conductivity, TDS, TSS, pH, Total hardness, calcium content, magnesium content, Total alkalinity, chloride, nitrate, o-Phosphate, and iron present in water samples. The results obtained reveal that the water quality of the area needs some degree of treatment before consumption. It therefore becomes imperative to regularly monitoring the quality of water to protect it. The objective of the present work is to compute water quality index values to assess the suitability of water for human consumption. Water level has a net positive effect on water quality in water body through dilution of environmental parameters. Consequently, local management agencies should pay more attention to nutrient concentrations during the monitoring schedule, as well as during the low-water periods which manifest a relatively bad water quality state.
\end{abstract}

\section{INTRODUCTION}

Surface water quality deterioration has become a serious concern worldwide due to increased pollution and climate change. The degradation of water quality in a water body creates adverse condition so that water cannot be used for intended beneficial uses including bathing, recreation and as a source of raw water supply.

WQI is an effective tool to assess the quality of water obtained by aggregating several water quality measurements into one number. It is one of the most effective tools to communicate information on the quality of water to the concerned citizens and policy makers.

This study was conducted on the Rajghat dam situated in Sagar District of Madhya Pradesh, India; First samples of selected 5 sampling places of Rajghat are tested for desired physico-chemical parameters to determined WQI values. The weightage is given to the parameters according to purpose where most 
influential/representative parameter for the purpose is given higher weightage than the less important one. The weighted average of the parameter will give the WQI of that sample for the desired purpose; next will be to select a standard for maximum and minimum permissible limit. Once the results from the sampling is available the weighted average of the values of the parameters are calculated. The influential parameter for drinking water is given higher weightage than the other less influential ones.

Generally from literature reviews it can be seen that a 100 point water quality index scale can be divided into several ranges corresponding to the general descriptive terms shown in the table below.

Table 1. Water Quality Index Legend

\begin{tabular}{|l|l|l|}
\hline Range & Quality & WQI \\
\hline $90-100$ & Excellent & Excellent \\
\hline $80-90$ & Good & Healthy \\
\hline $50-80$ & Medium & Alarming \\
\hline $25-50$ & Bad & Badly Affected \\
\hline $0-25$ & Very bad & Very Badly Affected \\
\hline
\end{tabular}

\section{STUDY AREA AND COLLECTION OF WATER SAMPLES}

The catchment area of Bewas river at the dam site is $472 \mathrm{Sq}$. Kms with 1700hectare submergence area, is located between $23^{\circ} 23^{\prime} 36^{\prime \prime} \mathrm{N}$ to $23^{\circ} 46^{\prime} 22^{\prime \prime} \mathrm{N}$ latitude and $78^{\circ} 30^{\prime} 32^{\prime \prime} \mathrm{E}$ to $78^{\circ} 46^{\prime} 42^{\prime \prime} \mathrm{E}$ longitude. The dam site is situated in three rivers i.e. Bewas River, Parkul River, and Jamunia River junction at Hinota village, Sagar (M. P.). The dam is $1680 \mathrm{~m}$ long with $400 \mathrm{~m}$ masonry spillway, and remaining $1280.0 \mathrm{~m}$ is constructed from stone, and soil. Water samples were collected from 5 sampling places of Reservoir. Each water sample was taken in PreMonsoon to Post Monsoon during May 2018 to March 2019. The temperatures of the samples were measured in the field on the spot at the time of sample collection. The samples were immediately analysed in the chemistry lab to minimize physico-chemical changes. The error due to time has been omitted for the present study. Each sample was analysis for, using procedures outline in the standard methods for the examination of water and wastewater APHA.

\section{METHOD AND METHODOLOGY}

All the chemicals used were of AR grade. Analysis was carried out for most water quality influencing 21 parameters with concerning units and test methods discussed in table (2). 
Table 2. List of Physico-chemical parameters and their test methods

\begin{tabular}{|l|l|c|l|}
\hline $\begin{array}{l}\text { N } \\
\text { o. }\end{array}$ & \multicolumn{1}{|c|}{ Parameters } & Unit & \multicolumn{1}{|c|}{ Test Methods } \\
\hline 1 & Water temperature & ${ }^{\circ} \mathrm{C}$ & Mercury-in-glass thermometer \\
\hline 2 & $\mathrm{pH}$ & - & $\mathrm{pH}$ meter \\
\hline 3 & Dissolved Oxygen $(\mathrm{DO})$ & $\mathrm{mg} / \mathrm{L}$ & Winkler method \\
\hline 4 & Conductivity & $\mathrm{ms} / \mathrm{cm}$ & Conductivity meter \\
\hline 5 & Alkalinity & $\mathrm{mg} / \mathrm{L}$ & Titration \\
\hline 6 & Total Suspended solids(TSS) & $\mathrm{mg} / \mathrm{L}$ & $\begin{array}{l}\text { Gravimetric (filtration and weighing of } \\
\text { residue) }\end{array}$ \\
\hline 7 & Total dissolved Solids & $\mathrm{mg} / \mathrm{L}$ & Digital conductivity meter (LT-51) \\
\hline 8 & Chloride & $\mathrm{mg} / \mathrm{L}$ & Argentometric titration \\
\hline 9 & Orthophosphate $\left(\mathrm{P}_{4}{ }^{3-}-\mathrm{P}\right)$ & $\mathrm{mg} / \mathrm{L}$ & $\begin{array}{l}\text { Ammonium molybdate ascorbic acid } \\
\text { reduction method }\end{array}$ \\
\hline 10 & Nitrate - Nitrogen $\left(\mathrm{NO}_{3}-\mathrm{N}\right)$ & $\mathrm{mg} / \mathrm{L}$ & Spectrophotometric method \\
\hline 11 & Total Hardness as $\mathrm{CaCO}_{3}$ & $\mathrm{mg} / \mathrm{L}$ & EDTA titration \\
\hline 12 & Iron & $\mathrm{mg} / \mathrm{L}$ & Colorimetric Method \\
\hline 13 & Ca Content & $\mathrm{mg} / \mathrm{L}$ & EDTA titrimetric method \\
\hline 14 & Mg Content & $\mathrm{mg} / \mathrm{L}$ & EDTA titrimetric method and calculation \\
\hline
\end{tabular}

For the desired purpose (say drinking or other uses). WQI may vary with respect to purpose and standards selected. For computing WQI, each of the parameters has been assigned a weight (wi) according to its relative importance in the overall quality of water for drinking purposes. The maximum weight assigned to that parameter by itself major importance in water quality assessment. Minimum weight assigned to that parameter by itself may not be harmful. The relative weight $\left(\mathrm{W}_{\mathrm{i}}\right)$ is computed from the following equation:

$$
\mathrm{W}_{\mathrm{i}}=\mathrm{w}_{\mathrm{i}} / \sum \mathrm{w}_{\mathrm{i}}, \quad \mathrm{i}=1 \text { to } \mathrm{n}
$$

Where, $\mathrm{W}_{\mathrm{i}}$ is the relative weight, $\mathrm{w}_{\mathrm{i}}$ is the weight of each parameter and $\mathrm{n}$ is the number of parameters. Calculated relative weight $\left(\mathrm{W}_{\mathrm{i}}\right)$ values of each parameter.

Cumulative relative weight factor (C.W.F.) is the sum of weight factor of all selected physico-chemical factors.

The mathematical relation used to calculate WQI is given as-

$$
\mathrm{WQI}=\Sigma \mathrm{Q} \text { i Wi } / \Sigma \mathrm{Wi}
$$


Where Q i - Quality rating scale

$\mathrm{Wi}$ - Relative weight, $\mathrm{Wi}=1 / \mathrm{Si}$ where $\mathrm{Si}$ - Std. permissible value $\mathrm{Q} \mathrm{i}=100[(\mathrm{Vn}-\mathrm{Vi}) /(\mathrm{Vs}-\mathrm{Vi})]$

$\mathrm{Vn}$ - actual or test value of the parameter, Vi- ideal value of the parameter Vs- Recommended WHO std of the parameter

The value of the physico-chemical parameters were compared with desirable/permissible limit of IS: 10500 drinking water specification. The regression analysis has been performed using by Winks SDA 6.0.5, SPSS 11.0 Statistical Software.

\section{RESULTS AND DISCUSSION}

A quality rating scale $\left(\mathrm{q}_{\mathrm{i}}\right)$ is consisted of various regression equations. For determination of Q-value, each parameter value is assigned by, after regression analysis of particular parameter (of specific season) with the mean concentration of that parameter of entire study (present in water sample), where mean parameter values taken as dependent variables and seasonal parameter values taken as independent variables, all the regression equations confined within the boundary of its respective standard maxima and minima (in $\mathrm{mg} / \mathrm{L}$ ). According to the guidelines laid down in the Indian drinking water standard for each parameter in $\mathrm{mg} / \mathrm{L}$ BIS: 10500, 1991/ICMR/CPCB/CGWB.

Table 3. Normal statistics of water quality parameters of reservoir water samples of Sagar city.

\begin{tabular}{|l|c|c|l|l|c|c|}
\hline Parameter & Mean & $\begin{array}{l}\text { Standard } \\
\text { Deviation }\end{array}$ & Sem & Min & Max & Sum \\
\hline Temperature & 25.158 & 1.312 & .257 & 22.300 & 28.600 & 654.10 \\
\hline pH & 7.7427 & .7601 & .1491 & 6.510 & 9.010 & 201.31 \\
\hline DO & 5.1377 & 1.7594 & .3450 & 2.280 & 7.850 & 133.58 \\
\hline Conductivity & .7938 & .3872 & .0759 & .450 & 1.560 & 20.64 \\
\hline Alkalinity & 233.962 & 83.061 & 16.290 & 104 & 375 & 6083 \\
\hline TS & 517.144 & 263.661 & 51.708 & 281.47 & 1048.27 & 13445.75 \\
\hline TSS & 32.780 & 30.452 & 5.972 & 3.360 & 96.420 & 852.28 \\
\hline TDS & 484.364 & 236.270 & 46.336 & 274.950 & 953.45 & 12593.47 \\
\hline Chloride & 77.630 & 45.733 & 8.969 & 28.640 & 194.43 & 2018.39 \\
\hline o-Phosphate & 3.5227 & 1.1211 & .2199 & 1.890 & 6.240 & 91.59 \\
\hline Nitrate & 4.5877 & 4.5568 & .8937 & 1.060 & 13.480 & 119.28 \\
\hline Total Hardness & 283.487 & 145.413 & 28.518 & 150.190 & 562.16 & 7370.65 \\
\hline Ca Content & 217.640 & 109.780 & 21.530 & 114.360 & 415.38 & 5658.64 \\
\hline Mg Content & 65.847 & 39.567 & 7.760 & 18.770 & 153.08 & 1712.01 \\
\hline Iron & 1.1908 & 1.2014 & .2356 & .150 & 3.640 & 30.96 \\
\hline
\end{tabular}


This water quality index also assessed impact of aquatic pollution on our environment. The standard objectives sheet by default loads all of the variables for which the BIS (IS: 10500-91)/ICMR/CPCB, New Delhi. Drinking water standards has developed water quality guidelines used as a reference.

This WQI model is 100 point scale that summarizes results from a total of 14 different water quality tests for possible inclusion in an index. Regression

Table 4. Relative weight of Physico-chemical parameters (mg/l)

\begin{tabular}{|c|c|c|c|}
\hline $\begin{array}{l}\text { Physico-Chemical } \\
\text { parameters }\end{array}$ & $\begin{array}{l}\text { Indian Standards/ } \\
\text { WHO/ CPCB, New } \\
\text { Delhi (ppm) }\end{array}$ & Weight (wi) & $\begin{array}{l}\text { Relative } \\
\text { weight (Wi) }\end{array}$ \\
\hline Total dissolved solids & $500-2,000$ & 10 & 0.10 \\
\hline Alkalinity & $200-600$ & 7 & 0.07 \\
\hline $\mathrm{pH}$ & $6.5-8.5$ & 10 & 0.10 \\
\hline Conductivity & $.750-3.0$ & 5 & 0.05 \\
\hline $\mathrm{TH}$ & $300-600$ & 6 & 0.06 \\
\hline Chloride & $250-1,000$ & 7 & 0.07 \\
\hline Water temperature & - & 6 & 0.06 \\
\hline DO & 6 or more & 10 & 0.10 \\
\hline o- Phosphate & Less than 0.05 & 7 & 0.07 \\
\hline Nitrate & $45-100$ & 7 & 0.07 \\
\hline Ca Content & $75-200$ & 7 & 0.07 \\
\hline Mg content & $30-100$ & 7 & 0.07 \\
\hline Iron & $0.3-1.0$ & 5 & 0.05 \\
\hline \multirow[t]{2}{*}{ TSS* } & 25 & 6 & 0.06 \\
\hline & & $\sum w i=100$ & $\sum \mathrm{Wi}=1.00$ \\
\hline
\end{tabular}

* $\mathrm{pH}$ (pH unit), Conductivity (in $\mathrm{ms} / \mathrm{cm}$ ), Water temperature $\left({ }^{\circ} \mathrm{C}\right)$

equation representing chemical analysis results of 5 sampling places of Rajghat reservoir of Sagar city. About 14 factors were chosen and some were judged more important than others, so a weighted mean is used to combine the values. So that field measurements could be converted to index values, when test results from fewer than all 14 measurements are available, we preserve the relative weights for each factor and scale the total so that the range remains 0 to 100 . After completing the experimental tests, the results recorded and transferred for statistical analysis in SPSS.11 and WINKS SDA software given regression equations. On input a data in regression equations, a numerical value is obtained. For each test, the numerical value or Q-value is multiplied by a "weighting factor." For example, $\mathrm{pH}$, dissolved oxygen and TDS have a relatively high weighting factor; because it is more 
significant in determining water quality than the other tests. The 14 resulting values are then added to arrive at an overall water quality index (WQI).

Table 5. Regression equation of various physico-chemical parameters

\begin{tabular}{|c|c|c|}
\hline $\begin{array}{l}\text { Dependent } \\
\text { Variable }\end{array}$ & $\begin{array}{l}\text { Independent } \\
\text { Variable }\end{array}$ & Regression equation \\
\hline Temperature mean & Temperature & Temperature $_{\text {mean }}=14.105+0.28093 *$ Temperature \\
\hline Conductivity mean & Conductivity & $\begin{array}{c}\text { Conductivity mean }= \\
0.3128366+0.340114 * \text { Conductivity }\end{array}$ \\
\hline $\mathrm{TDS}_{\text {mean }}$ & TDS & $\mathrm{TDS}_{\text {mean }}=163.27+0.5436 * \mathrm{TDS}$ \\
\hline $\mathrm{TH}_{\text {mean }}$ & TH & Total Hardness ${ }_{\text {mean }}=112.279+0.4258 * \mathrm{H}$ \\
\hline $\mathrm{pH}_{\text {mean }}$ & $\mathrm{pH}$ & $\mathrm{pH}_{\text {mean }}=7.7142+0.4035 * \mathrm{pH}$ \\
\hline Alkalinity mean & Alkalinity & Alkalinity $_{\text {mean }}=31.464+0.572103 *$ Alkalinity \\
\hline Chloride $_{\text {mean }}$ & Chloride & Chloride $_{\text {mean }}=9.7802+.89036 *$ Chloride \\
\hline Nitrate $_{\text {mean }}$ & Nitrate & Nitrate $_{\text {mean }}=1.018+0.2790 *$ Nitrate \\
\hline $\mathrm{DO}_{\text {mean }}$ & DO & $\mathrm{DO}_{\text {mean }}=6.08+0.2602 *$ Dissolved Oxygen \\
\hline Iron $_{\text {mean }}$ & Iron & Iron $_{\text {mean }}=0.195+0.3515 *$ Iron \\
\hline Ca content mean & Ca content & Ca content $t_{\text {mean }}=38.715+0.59742 *$ Ca content \\
\hline $\mathrm{Mg}$ content ${ }_{\text {mean }}$ & Mg content & $\mathrm{Mg}$ content $_{\text {mean }}=8.723+0.51521 * \mathrm{Mg}$ content \\
\hline O-phosphate mean & O-phosphate & O-phosphate mean $=1.18+5.674 \mathrm{E}-02 *$ O-phosphate \\
\hline $\mathrm{TSS}_{\text {mean }}$ & TSS & $\mathrm{TSS}_{\text {mean }}=26.45+0.42103 * \mathrm{TSS}$ \\
\hline
\end{tabular}

\section{CONCLUSIONS}

Application of Water Quality Index (WQI) in this study has been found useful in assessing the overall quality of water and to get rid of judgment on quality of the water. This particular model allows the user to input site-specific objectives, or to utilize the guidelines for various parameters.

This method appears to be more systematic and gives comparative evaluation of the water quality of sampling stations. There are some limitations of WQI. For instance, WQI may not carry enough information about the real quality situation of the water. Also many uses of water quality data cannot be met with an index. But there are more advantages of WQI than disadvantages. It is recommended that analysis should be carried out from time to time to monitor the rate and kind of contamination. 


\section{References}

APHA (1992), Standard Methods for the Examination of Water and Wastewater (American public health association publication, 18th edition, Washington DC), ISBN 0-87553131-8, ISSN 8755-3546.

Central Pollution Control Board, New Delhi. (2007), Guidelines for Water Quality Monitoring, Website: http://www.cpcb.nic.in

Indian standard drinking water, Specification (First Revision) IS-10500:1991. BIS, New Delhi, India

Pathak, H., Limaye, S.N. (2011), Pollumeter: A Water Quality Index model for the assessment of water quality in Sagar city, M.P., India. The Green Pages: Directory for Environmental Technology.

Pathak, H., Limaye, S.N. (2011), Interdependency between physico chemical water pollution indicators: a case study of river Babus, Sagar, M.P., India. Analele UniversităŃii din Oradea - Seria Geografie, Year XXI, no. 1/2011 (June), ISSN 14542749, E-ISSN 2065-1619

Pathak, H., Limaye, S.N. (2012), Indicators of the deteriorate water quality status of reservoir, Sagar city, MP, India by multivariate analysis, Ovidius University Annals of Chemistry, 23(2), pp.155-162, ISSN-1223-7221.

Pathak, H., Limaye, S.N. (2012), Studies on the physico-chemical status of two water bodies at Sagar city under anthropogenic Influences, Advances in Applied Science Research (Pelagia Research Library), 3 (1), pp. 31-44, ISSN: 0976-8610 [link]

Pathak Hemant (2012), Evaluation of ground water quality using multiple linear regression and mathematical equation modeling, Analele Universităii din Oradea Seria Geografie, vol. 2, ISSN 1454-2749 [link]

Pathak, H. (2013), Water quality Studies of two Rivers at bundelkhand region, MP, India: A case study, U.P.B. Sci. Bull., Series B, 75(2), ISSN 1454-2331. [link]

Pathak, H. (2015), Effect of water quality parameter on fish culture in Lake with reference to statistical approach, The Bulletin of the Polytechnic Institute of IAȘI, vol. (2), pp. 15-20, ISSN: $0254-7104$.

Pathak, H. (2019), Overview of Ground Water Decline Situation in Perspective of Current Policy in India, Annals of Ecology and Environmental Science, 3(1),pp. 20-22, ISSN; 2637-5338.

Ramakrishnaiah C. R., Sadashivaiah C., Ranganna G. (2009), Assessment of Water Quality Index for the Groundwater in Tumkur Taluk, Karnataka State, India, EJournal of Chemistry, 6(2), 523-530, DOI: https://doi.org/10.1155/2009/757424

Ramesh S., Sukumaran N., Murugesan A. G., Rajan M. P. (2010), An innovative approach of Drinking Water Quality Index - A case study from Southern Tamil Nadu, India, Ecological Indicators, 10(4), 857-868, DOI: https://doi.org/10.1016/j.ecolind.2010.01.007

(C) 2020 by the authors. Licensee UAIC, Iasi, Romania. This article is an open access article distributed under the terms and conditions of the Creative Commons Attribution (CC BY-NC-ND) license (https://creativecommons.org/licenses/by-nc-nd/4.0). 